\title{
EFEKTIVIAS MODEL PEMBELAJARAN FLIPPED CLASSROOM DARING MENGGUNAKAN MEDIA SOSIAL INSTAGRAM DI KELAS X SMK
}

\author{
Puri Sinatrya ${ }^{1)}$ \\ Singgih Utomo $\mathrm{Aji}^{2}$ \\ 1), 2) Program Studi Pendidikan Matematika, Universitas Sanata Dharma \\ Email: ${ }^{1)}$ purisinatrya@gmail.com, \\ 2) singgihaji33@gmail.com
}

\begin{abstract}
ABSTRAK
- Penelitian ini dilakukan saat masa pandemi COVID-19, sehingga seluruh pembelajaran dilakukan secara daring. Salah satu model pembelajaran yang cocok digunakan saat masa pandemi ini adalah model pembelajaran flipped classroom. Model pembelajaran flipped classroom merupakan salah satu model belajar dengan cara siswa mempelajari materi ketika berada di luar kelas dan ketika di kelas, siswa mengerjakan latihan soal dan diskusi mengenai materi yang belum dipahami. Media sosial Instagram dipilih karena media ini sangat dekat dengan remaja setara dengan SMK (Sekolah Menengah Kejuruan). Penelitian ini bertujuan untuk menguji keefektifan belajar model pembelajaran kelas terbalik di kelas X SMK dengan menggunakan memanfaatkan media sosial Instagram pada materi Barisan dan Deret Aritmetika dan Geometri. Metode penelitian yang dilakukan adalah penelitian kuantitatif dan deskriptif kualitatif. Teknik pengumpulan data meliputi pre-test, post-test, wawancara, dan angket terbuka untuk seluruh siswa. Uji $t$ dilakukan untuk menganalisis hasil pre-test dan post-test, dan analisis deskriptif kualitatif digunakan untuk menganalisis hasil wawancara dan angket terbuka. Dari hasil penelitian dapat disimpulkan bahwa terdapat peningkatan hasil belajar siswa yang menandakan bahwa model pembelajaran kelas terbalik daring dengan menggunakan media sosial Instagram efektif dilakukan. Selain itu, pembelajaran seperti ini juga menambah pengalaman baru bagi siswa yang dirasa efektif dilakukan dalam pembelajaran.
\end{abstract}

Kata kunci: Kelas Terbalik, Instagram, Barisan dan Deret, Aritmetika, Geometri

\begin{abstract}
This research was conducted during the COVID-19 pandemic, so all learning was carried out online. One of the learning models suitable for use during this pandemic is the flipped classroom learning model. The flipped class learning model is one of the learning models in which students learn material when they are outside the classroom and when in class, students do exercises and discussions about material that has not been understood. Social media Instagram was chosen because this media is very close to teenagers, equivalent to SMK (Vocational High School). This study aims to test the effectiveness of learning the reverse class learning model in class X SMK by using social
\end{abstract}


media Instagram on the Arithmetic and Geometry Line and Series material. The research method used is quantitative and descriptive qualitative research. Data collection techniques include pre-test, post-test, interviews, and open questionnaires for all students. The technique of pre-test and post-test results analysis used the t test method, while the results of interviews and open questionnaires used descriptive qualitative analysis. From the results of the study it can be concluded that there is an increase in student learning outcomes which indicates that the online flipped classroom learning model using Instagram social media is effective. In addition, learning like this also adds new experiences for students that are considered effective in learning.

Keywords: Flipped Classroom, Instagram, Sequences and Series, Arithmetic, Geometric

\section{PENDAHULUAN}

Pada saat ini, teknologi berkembang pesat di seluruh dunia. Dapat disaksikan bahwa perkembangan teknologi ini membawa gaya hidup tidak terlepas dari koneksi internet, tidak terkecuali Indonesia. Saat ini masyarakat selalu mendapatkan informasi dengan mudah dan begitu cepat dari media sosial atau internet. Perkembangan teknologi yang begitu pesat juga merambah ke dunia pendidikan. Salah satu dampak dari pesatnya perkembangan teknologi adalah terdapat berbagai macam media sosial yang dapat dimanfaatkan sebagai media pembelajaran bagi siswa. Salah satu media sosial yang dapat digunakan adalah Instagram.

Instagram merupakan aplikasi media sosial pada ponsel pintar yang berfungsi untuk mengambil foto atau mengabadikan foto maupun video di akun pengguna, menggunakan filter pada foto, dan berbagi foto ke berbagai media sosial, termasuk Instagram sendiri (Utami, Probosari, \& Fatmawati, 2015). Berdasarkan survei pada Januari 2020, media sosial Instagram 79\% digunakan oleh penduduk Indonesia yang berumur 16 - 64 tahun (Kemp, 2020). Instagram juga dapat memberikan inspirasi dan meningkatkan kreativitas bagi penggunanya, dikarenakan Instagram memiliki fitur editing foto yang membuatnya lebih bagus dan menarik (Atmoko, 2012). Selain itu, media sosial Instagram memiliki beberapa fitur menarik, seperti fitur komentar untuk memberikan komentar pada suatu unggahan, fitur berbagi untuk membagikan unggahan Instagram ke lebih banyak pengguna Instagram lain, dan masih banyak fitur Instagram yang dapat dimanfaatkan untuk mendukung media sosial Instagram ini sebagai media pembelajaran. Mahendra (2017) mengatakan bahwa dengan banyaknya pertemanan pada media sosial Instagram, akan mendapatkan lebih banyak informasi yang berguna, begitu pula dengan pengguna lain yang dapat berperan sebagai pemberi informasi kepada pengguna lain. Hal ini diharapkan agar akun media sosial yang dibuat oleh peneliti tidak berhenti pada lingkup subjek penelitian saja, tetapi dapat bermanfaat bagi orang lain di sekitar subjek penelitian.

Melalui kepopuleran media sosial Instagram, media sosial ini dapat digunakan sebagai media pembelajaran. 
Jika dilihat, pembelajaran yang dilakukan secara daring membuat siswa belajar kurang maksimal karena posisinya tidak bertemu secara langsung dengan guru. Siswa dituntut untuk belajar secara mandiri dan tidak hanya mengandalkan guru dalam kondisi seperti ini. Masalah ini dapat diatasi dengan model pembelajaran flipped classroom. Damayanti dan Sutama (2016) mengatakan bahwa flipped classroom merupakan model pembelajaran yang umumnya dilakukan di dalam kelas akan dilakukan di luar kelas atau di rumah. Namun, ketika berada di kelas, kegiatan siswa hanya membahas dan mendiskusikan hal-hal yang sudah dipelajari di luar kelas. Bishop dan Verleger (2013) menyatakan bahwa flipped classroom memiliki dua arti, yaitu arti luas dan arti sempit. Flipped classroom dalam arti sempit yaitu ketika di luar kelas siswa dapat menonton video pembelajaran dan ketika di dalam kelas, siswa dapat mengerjakan latihan soal maupun mengerjakan tugas yang diberikan. Sedangkan flipped classroom dalam arti luas yaitu ketika di luar kelas siswa tidak hanya menonton video pembelajaran, tetapi siswa dapat menyelesaikan latihan yang bersifat tertutup dan ketika berada di dalam kelas terdapat aktivitas diskusi untuk memecahkan masalah yang bersifat terbuka. Model pembelajaran flipped classroom memiliki kelebihan, seperti (1) siswa memiliki waktu lebih untuk belajar, (2) siswa dapat mempelajari materi sesuai kondisi dan suasana yang nyaman, (3) siswa mendapatkan perhatian penuh dari guru,
(4) siswa dapat belajar dari berbagai konten (Yulietri, Mulyoto, \& S, 2015).

Model pembelajaran flipped classroom memiliki potensi untuk diterapkan ketika masa pandemi sudah berakhir maupun sedang di masa pandemi seperti sekarang ini karena model pembelajaran flipped classroom memiliki sifat yang fleksibel, yaitu dapat dilakukan secara langsung (tatap muka) atau dalam jaringan (Tolks, dkk., 2020). Dari penjelasan di atas, model pembelajaran flipped classroom dapat membuat kondisi siswa untuk belajar di luar kelas atau di luar jam pelajaran, sehingga sangat memungkinkan untuk diaplikasikan saat pembelajaran jarak jauh (PJJ) mengingat ketika penelitian ini dilaksanakan saat masa pandemi COVID-19 yang memaksa semua pembelajaran dilakukan dalam jaringan. Selain itu, bagi guru yang menerapkan model pembelajaran flipped classroom dalam jaringan ini tidak akan terlalu banyak memiliki beban pengajaran dikarenakan siswa sudah belajar secara mandiri di luar jam efektif belajar di kelas (Tolks, dkk., 2020).

Oleh karena itu, dalam hal ini penulis akan menerapkan model pembelajaran flipped classroom dalam jaringan dengan menggunakan media sosial Instagram pada materi barisan dan deret aritmetika dan geometri. Penulis juga akan mengkaji efektivitas penerapan model pembelajaran flipped classroom daring dengan menggunakan media sosial Instagram pada materi barisan dan deret aritmetika dan geometri serta mencari faktor-faktor yang mempengaruhi model pembelajaran tersebut. 


\section{METODE PENELITIAN}

Metode yang digunakan penulis dalam melakukan penelitian ini adalah metode eksperimen-kuasi (quasiexperiment) dengan rancangan satu kelompok pra-perlakuan dan pascaperlakuan (one group pre-test - post-test design). Pengukuran pra-perlakuan memberikan informasi mengenai sebelum diberikannya kondisi khusus pada subjek sedangkan pengukuran pasca-perlakuan memberikan informasi setelah dilakukan perlakuan khusus (Hastjarjo, 2019). Pada penelitian ini perlakuan khusus berupa pembelajaran menggunakan model pembelajaran flipped classroom secara dating dengan memanfaatkan media sosial Instagram. Penelitian ini juga menggunakan pendekatan deskriptif kualitatif dan kuantitatif. Kemudian, terdapat observasi pembelajaran yang telah dilaksanakan.

Penelitian ini dilaksanakan di kelas X SMK Negeri di Yogyakarta. Sampel yang digunakan pada penelitian ini berjumlah 31 siswa. Penelitian ini dilakukan 3 kali pertemuan dengan topik materi Barisan dan Deret Aritmetika dan Geometri. Pertemuan pertama diawali dengan pelaksanaan pre-test kemudian dilanjutkan dengan pembelajaran. Pertemuan kedua dan ketiga selama 4 JP dilakukan pembelajaran, kemudian pada akhir pertemuan ketiga dilaksanakan post-test. Instrumen penelitian yang digunakan adalah soal tes (pre-test dan post-test), pedoman wawancara, dan rancangan pelaksanaan pembelajaran (RPP). Sebelum melaksanakan penelitian, terlebih dahulu dilakukan validasi terhadap instrumen. Pada penelitian ini, instrumen penelitian telah di validasi oleh 2 orang validator. Selama melakukan pengajaran, digunakan model pembelajaran flipped classroom dengan menggunakan media sosial Instagram sebagai media pembelajaran. Nama pengguna Instagram yang dipergunakan selama melakukan penelitian adalah @ belajar.asik_k. Pada akun tersebut diunggah materi Barisan dan Deret Aritmetika dan Geometri berupa foto maupun video.

Instrumen yang digunakan untuk mengumpulkan data pre-test dan posttest adalah 8 butir soal pilihan ganda. Pre-test dan post-test digunakan untuk mengukur keefektifan model pembelajaran flipped classroom ditinjau dari hasil belajar siswa. Selain itu, juga terdapat wawancara dan angket terbuka untuk mengetahui faktor-faktor yang memengaruhi keefektifan dari model pembelajaran ini serta dapat mengetahui kelemahan dan kelebihan dari penelitian ini.

Analisis data dalam penelitian ini dilakukan dengan menggunakan teknik analisis data kuantitatif dan kualitatif. Analisis data kuantitatif dilakukan untuk nilai pre-test, post-test, dan validasi instrumen penelitian. Data nilai pre-test dan post-test dianalisis dengan menggunakan uji $\mathrm{t}$ sampel-sampel berpasangan, sedangkan data hasil validasi instrumen penelitian dianalisis dengan menggunakan statistik deskriptif. Sebelum melakukan uji $\mathrm{t}$ sampel-sampel berpasangan, terlebih dahulu dilakukan uji normalitas pada sampel. Didapatkan bahwa sampel berasal dari distribusi normal, maka 
dapat langsung dilakukan uji-t. Analisis data kualitatif digunakan untuk merangkum data hasil wawancara dan angket terbuka.

\section{HASIL PENELITIAN DAN PEMBA- HASAN}

Setelah dilakukan penelitian, maka didapatkan beberapa hasil penelitian, yaitu hasil validasi instrumen penelitian, hasil pre-test dan post-test, implementasi flipped classroom daring dengan menggunakan media sosial Instagram, hasil angket terbuka, dan hasil wawancara.

Instrumen penelitian yang digunakan selama penelitian adalah Rancangan Pelaksanaan Pembelajaran (RPP), pedoman wawancara, dan soal tes. Instrumen penelitian ini divalidasi oleh 2 orang validator. Instrumen ini divalidasi oleh 1 orang dosen Pendidikan Matematika dan 1 orang mahasiswa S2 Pendidikan Matematika.

Hasil validasi RPP diperoleh rerata skor $79,17 \%$, pedoman wawancara $78,00 \%$, dan soal tes $73,75 \%$. Terlihat hasil validasi bahwa rerata skor instrumen yang digunakan melebihi 70\%, maka instrumen penelitian dapat dinyatakan valid dan dapat digunakan. Pada kolom keterangan masih dinyatakan layak digunakan dengan revisi, yang menandakan bahwa instrumen yang dibuat belum sempurna, maka diperlukan revisi. Saat melaksanakan pre-test, proses validasi belum selesai maka kami menggunakan soal tersebut dengan sedikit revisi. Namun, saat pelaksanaan post-test seluruh soal tes yang perlu direvisi, sudah direvisi seluruhnya. Maka dapat dinyatakan bahwa soal tes sudah valid.

Pembelajaran pada umumya penulis memberikan materi di dalam kelas kemudian memberikan contoh soal dan pembahasan kemudian memberikan waktu bagi siswa untuk berlatih mengerjakan latihan soal. Penulis menggunakan berbagai macam model pembelajaran agar siswa tidak merasa bosan. Model pembelajaran yang sering digunakan oleh penulis adalah model pembelajaran flipped classroom. Konsep dari flipped classroom sendiri menurut Bergmann dan Sams (dalam Maolidah, Ruhimat, \& Dewi, 2017:164) yaitu mempelajari materi yang seharusnya dilakukan di kelas, kemudian kegiatan di kelas adalah mengerjakan soal-soal latihan yang seharusnya dikerjakan di rumah.

Model pembelajaran flipped classroom ini memberikan waktu lebih banyak bagi siswa untuk mempelajari materi dan melakukan diskusi. Selain itu, model pembelajaran flipped classroom juga mengajarkan siswa untuk lebih mandiri. Sehingga ketika pembelajaran berlangsung banyak terjadi kegiatan yang dilakukan oleh guru dengan siswa maupun kegiatan antar siswa. Model pembelajaran flipped classroom yang digunakan dalam penelitian ini seluruhnya dilakukan dalam jaringan, mulai dari pembukaan, pemberian materi, diskusi, hingga kegiatan penutup. Diskusi berjalan baik selama pembelajaran meskipun harus diberikan umpan terlebih dahulu. Siswa terlihat kurang aktif, mungkin karena sudah mengalami kebosanan dengan pembelajaran yang sudah dilakukan 
secara daring selama kurang lebih 8 bulan terakhir.

Terdapat berbagai macam media yang digunakan oleh guru selama melakukan pembelajaran daring. Pada penelitian ini digunakan WhatsApp Group, Google Classroom, dan media sosial Instagram. WhatsApp Group digunakan sebagai ruang kelas yaitu untuk kegiatan pembuka, inti, dan penutup pembelajaran. Google Classroom digunakan sebagai media pengumpulan tugas. Sedangkan media sosial Instagram digunakan sebagai media pemberi materi kepada siswa.

Pada penelitian ini difokuskan pada penggunaan media sosial Instagram. Media sosial Instagram dipilih karena dapat membagikan momen berupa foto maupun video. Foto maupun video ini dimanfaatkan untuk mengunggah materi pembelajaran. Maka dari itu, media sosial Instagram ini dapat dijadikan sebagai media pembelajaran. Media ini dipilih karena sangat dekat juga dengan kehidupan remaja setara SMA / SMK.

Pembelajaran diawali dengan salam seperti pembelajaran pada umumnya, kemudian meminta siswa untuk melakukan presensi. Sebelum pembelajaran dimulai, penulis sudah memberikan penjelasan materi berupa foto yang telah diunggah pada media sosial Instagram. Tidak lupa, penulis juga memberikan video pembelajaran berupa pembahasan latihan soal, dengan harapan siswa dapat memahami penyelesaian dari soal yang diberikan. Hal ini bertujuan untuk memberikan waktu lebih bagi siswa untuk memahami topik yang akan dipelajari pada pertemuan mendatang. Sehingga ketika pembelajaran di kelas, kegiatan yang dilakukan siswa adalah mengerjakan latihan soal dan mendiskusikan hal-hal yang dianggap belum dipahami.

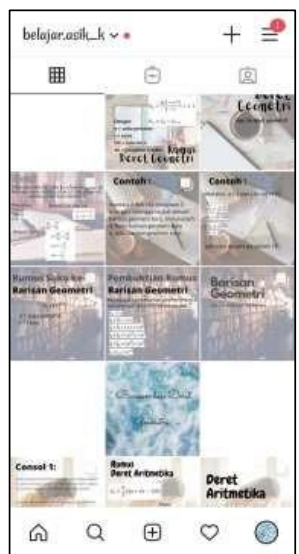

Gambar 1. Profil Media Sosial Instagram @belajar.asik_k

Media sosial Instagram memiliki daya tarik tersendiri bagi siswa. Media sosial Instagram sering kali dijadikan sebagai media hiburan bagi siswa ketika sudah merasa suntuk. Intensitas siswa dalam menggunakan media sosial Instagram cukup besar, menandakan antusiasme siswa yang besar. Antusiasme siswa dalam penggunaan Instagram sebagai media pembelajaran ini ditandai dengan banyaknya penonton atau penyuka foto maupun video yang diunggah. Tidak hanya itu, jika penulis mengunggah materi pembelajaran, seringkali beberapa siswa langsung menyukai unggahan tersebut. Jika telah menyukai suatu unggahan, minimal siswa sudah membaca isi unggahan walaupun hanya sekilas.

Setelah dilakukan penelitian selama 3 pertemuan di kelas X SMK, terlihat bahwa terjadi peningkatan rerata hasil belajar siswa. Rerata nilai pre-test 
siswa sebelum mempelajari topik Barisan dan Deret Aritmetika dan Geometri adalah 63,31. Kemudian setelah dilakukan pembelajaran dengan model pembelajaran flipped classroom daring dengan menggunakan media sosial Instagram, rerata nilai post-test siswa menjadi 96,37.

Tabel 1. Rerata Nilai Pre-test dan Post-

\begin{tabular}{cc} 
test & \\
\hline Pre-test & Post-test \\
\hline$n=31$ & $n=31$ \\
\hline $\bar{x}=63,31$ & $\bar{x}=96,37$ \\
\hline
\end{tabular}

Setelah dilakukan uji normalitas, sampel berasal dari distribusi normal. Simpangan baku dari selisih nilainya adalah 19,05. Karena data yang didapatkan merupakan data berpasangan dan tidak bebas, maka digunakan distribusi t-student untuk mengetahui apakah terdapat selisih antara sampel pre-test dan post-test. Setelah dilakukan uji- $t$ sampel-sampel berpasangan diperoleh $t(30)=9,31$ dan $p<$ 0,0001 . Dengan demikian, rerata nilai post-test lebih besar dari rerata nilai pretest secara signifikan.

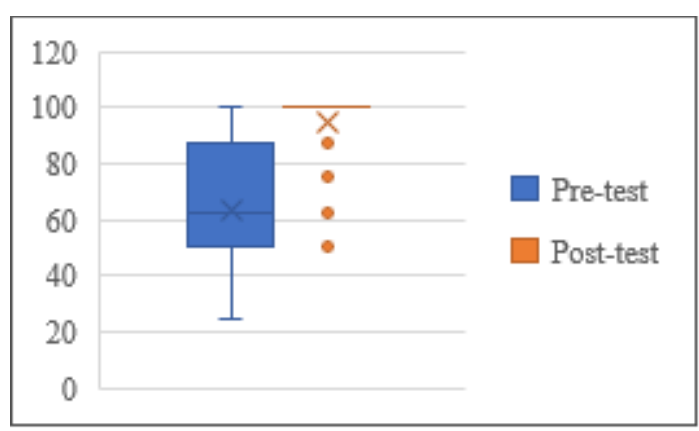

Gambar 2. Grafik Perbedaan Nilai Pretest dan Post-test

Setelah melakukan analisis kesimpulan yang didapat adalah terdapat cukup bukti bahwa nilai pre-test dan post-test memiliki rerata nilai yang berbeda. Kemudian jika dilihat dari rerata nilai pre-test dan post-test mengalami kenaikan yang signifikan pada post-test. Melihat rerata nilai posttest yang mengalami kenaikan maka dapat ditarik kesimpulan bahwa pembelajaran dengan memanfaatkan media sosial Instagram menggunakan model pembelajaran flipped classroom yang seluruhnya dilakukan dalam jaringan merupakan pembelajaran yang efektif.

Pembelajaran menggunakan model pembelajaran flipped classroom yang seluruh kegiatan pembelajarannya dalam jaringan dengan memanfaatkan media sosial Instagram dikatakan efektif. Hal ini dikuatkan dengan pernyataanpernyataan yang dituliskan oleh siswa pada angket terbuka. Selain itu, penulis juga melakukan wawancara untuk memastikan bahwa benar adanya jika pembelajaran dengan menggunakan model pembelajaran flipped classroom dengan memanfaatkan media sosial Instagram efektif dilakukan.

Hasil pemberian angket terbuka yaitu beberapa siswa merasakan bahwa pembelajaran dengan menggunakan media sosial Instagram ini merupakan pengalaman baru. Melalui foto atau video yang diunggah pada Instagram membuat materi menjadi lebih ringkas dan mudah dipahami siswa. Dipilihnya Instagram menjadi media yang digunakan pada model pembelajaran flipped classroom ini adalah karena sebagian besar siswa lebih sering membuka media sosial Instagram, maka dirasa efektif. Di sisi lain masih juga 
terdapat kendala pada siswa yaitu penggunaan kuota yang berlebih karena media sosial Instagram ini cukup memakan kuota yang banyak. Tidak sedikit siswa juga yang mengeluh akibat materi yang diberikan di media sosial Instagram, karena jika sudah membuka aplikasi Instagram biasanya untuk hiburan mereka, bukan untuk belajar dan menerima materi.

Setelah pemberian angket terbuka, peneliti memilih secara acak beberapa siswa yang akan diwawancara. Wawancara ini bertujuan untuk memberikan penguatan bahwa pembelajaran dengan memanfaatkan Instagram menggunakan model pembelajaran flipped classroom dikatakan efektif. Peneliti memilih secara acak 3 siswa untuk dilakukan wawancara.

Subjek 1 mengatakan bahwa pembelajaran dengan memanfaatkan Instagram efektif, foto atau video yang diunggah juga sangat menarik sehingga materi pun menjadi mudah dipahami. Foto dan video yang diunggah sudah meringkas materi yang akan dipelajari dan rumus-rumus yang diberikan sudah terdapat penyelesaiannya. "Kalau di Instagram itu enak mbak, sudah langsung ada rumus, terus ada contoh soal dan penyelesaiannya, jadi mudah dipaham", ujar subjek 1 ketika diwawancarai. Tetapi, subjek 1 juga masih mengalami kesulitan yaitu belum memahami perhitungan dikarenakan masih ada rumus yang belum dipahami.

Subjek 2 mengatakan ketika peneliti melakukan pengajaran di dalam kelas masih terlalu cepat dalam menjelaskan, sehingga subjek 2 merasa tertinggal. Jika hanya diberikan foto, masih sulit memahami materi, tetapi jika diberikan video mungkin subjek 2 akan lebih mudah memahami materi. Subjek 2 juga berpendapat bahwa foto dan video yang diunggah menarik, tetapi masih kesulitan dalam memahami foto. "Video pembelajaran sama foto-foto yang diunggah menarik mbak, berwarna", jelas subjek 2. Subjek 2 ini masih mengalami kesulitan pada salah satu topik yang ada pada bab Barisan dan Deret Aritmetika dan Geometri.

Subjek terakhir yang diwawancarai oleh peneliti mengatakan bahwa pembelajaran dengan memanfaatkan Instagram lebih mudah dipahami karena materi yang diberikan berupa ringkasan. "Saya merasa lebih mudah dalam mencatat karena materi yang diberikan sudah ringkas, tampilannya juga cukup menarik, sudah ada contoh soal dan pembahasan juga", tutur subjek 3. Selain itu foto-foto yang diunggah juga memuat contoh soal dan penyelesaian, sehingga mudah dipahami. Tampilan dari foto-foto yang diunggah juga cukup menarik sehingga tidak menyebabkan kebosanan. Subjek 3 ini masih belum memahami salah satu rumus dalam bab Barisan dan Deret Aritmetika dan Geometri.

Model pembelajaran flipped classroom dengan menggunakan media sosial Instagram pada materi Barisan dan Deret Aritmetika dan Geometri efektif digunakan dalam kegiatan pembelajaran. Hal tersebut dibuktikan dengan melihat Gambar 2 yang menunjukkan bahwa nilai pre-test dan post-test memiliki rerata nilai yang berbeda. Nilai tersebut menjelaskan 
bahwa rerata nilai post-test lebih baik daripada nilai pre-test. Dalam hal ini, siswa juga lebih antusias dalam mengikuti kegiatan pembelajaran yang menggunakan media sosial Instagram.

Berdasarkan penelitian yang dilakukan oleh Khasana (2020) yang meneliti mengenai pengaruh penggunaan media sosial Instagram. Hasil dari penelitian tersebut menyatakan bahwa penggunaan media sosial Instagram dapat berpengaruh terhadap hasil belajar siswa. Hal ini dikarenakan aplikasi Instagram dapat mempermudah kegiatan belajar siswa. Selain itu, siswa juga lebih tertarik menggunakan media sosial Instagram daripada membuka buku pelajaran. Maka media sosial Instagram merupakan media sosial yang efektif digunakan sebagai media pembelajaran.

Sedangkan faktor-faktor yang mempengaruhi keefektifan model pembelajaran flipped classroom dengan menggunakan media Instagram adalah seringnya siswa menggunakan aplikasi Instagram. Selain itu Instagram juga merupakan aplikasi favorit remaja yang duduk di bangku SMA / SMK. Pemberian materi sebelum pembelajaran berlangsung efektif karena memberikan lebih banyak waktu bagi siswa untuk mempelajari materi tersebut terlebih dahulu.

Secara umum, siswa memiliki persepsi positif terhadap pembelajaran flipped classroom, mereka menganggap aktivitas pra-pembelajaran sebagai fase yang berguna dalam pengalaman belajar mereka serta penggunaan video dapat meningkatkan pembelajaran mereka di lingkungan belajar siswa. (Kristanto \& Padmi, 2019)

\section{KESIMPULAN}

Berdasarkan analisis dan pembahasan, maka diperoleh simpulan sebagai berikut. Pembelajaran dengan model pembelajaran flipped classroom dengan menggunakan media sosial Instagram efektif digunakan dalam kegiatan pembelajaran. Hal ini dibuktikan dengan kenaikan yang signifikan antara pre-test dan post-test. Digunakannya model pembelajaran flipped classroom daring ini dapat disimpulkan bahwa siswa kelas X SMK merasakan pembelajaran yang lebih efektif karena pembelajaran di kelas tidak terlalu lama dan terlihat antusiasme siswa yang besar karena pembelajarannya menggunakan media sosial Instagram. Pembelajaran menggunakan media sosial Instagram ini juga merupakan pengalaman baru bagi siswa. Kemudian, faktor-faktor yang mempengaruhi keefektifan model pembelajaran flipped classroom daring menggunakan media sosial Instagram adalah intensitas siswa dalam mengakses media sosial Instagram, sehingga siswa lebih mudah dalam penggunaannya. Kelemahan dari penelitian ini adalah masih terdapat siswa yang tidak menggunakan aplikasi Instagram sehingga penulis perlu memberikan materi yang diunggah pada Instagram kepada siswa melalui WhatsApp Grup. 


\section{DAFTAR PUSTAKA}

Atmoko, B. D. (2012). Instagram Handbook Tip Fotografi Ponsel. Media Kita.

Bishop, J. L., \& Verleger, M. A. (2013). The Flipped classroom: A Survey of the Research. Atlanta: 120th ASEE Annual Conference \& Exposition.

Damayanti, H. N., \& Sutama, S. (2016). Efektivitas flipped classroom terhadap sikap dan keterampilan belajar matematika di SMK. Jurnal Manajemen Pendidikan, 11(2), 1-7.

Hastjarjo, T. D. (2019). Rancangan eksperimen-kuasi. Buletin Psikologi, 27(2), 187-203.

Kemp, S. (2020). Digital 2020: Indonesia.

https://datareportal.com/reports/di gital-2020-indonesia

Khasana, V. A., Setiyawan, H., \& Desiningrum, N. (2020). Pengaruh aplikasi Instagram terhadap hasil belajar siswa kelas $\mathrm{V}$ mata pelajaran matematika materi volume bangun ruang di SDN Bakung Temenggungan Balongbendo Sidoarjo. Child Education Journal, 2(2), 83-91.

Kristanto, Y. D., \& Padma, R. S. (2020). Flipping A Statistics Classroom for Pre-Service English Language Teachers. arXiv preprint arXiv:2002.05530.

Mahendra, B. (2017). Eksistensi Sosial Remaja dalam Instagram (Sebuah
Perspektif Komunikasi). Jurnal Visi Komunikasi, 16(1), 151-160.

Maolidah, I. S., Ruhimat, T., \& Dewi, L. (2017). Efektivitas penerapan model pembelajaran flipped classroom pada peningkatan kemampuan berpikir kritis siswa. Educational Tehcnologia, 3(2), 160-170.

Tolks, D., Romeike, B. F., Ehlers, J., Kuhn, S., Kleinsorgen, C., Huber, J., .. \& Hege, I. (2020). The online inverted classroom model (oICM). A blueprint to adapt the inverted classroom to an online learning setting in medical and health education. MedEdPublish, 9.

Utami, R. P., Probosari, R. M., \& Fatmawati, U. (2015). Pengaruh model pembelajaran project based learning berbantuan Instagram terhadap kemampuan berpikir kreatif siswa kelas X SMA Negeri 8 Surakarta. Bio-Pedagogi: Jurnal Pembelajaran Biologi, 4(1), 4752.

Yulietri, F., Mulyoto, M., \& S, L. A. (2015). Model flipped classroom dan discovery learning pengaruhnya ditinjau terhadap prestasi belajar matematika ditinjau dari kemandirian belajar. Jurnal Teknodika, 13(2), 5-17. 